\title{
KONEC REŠEVANJA VOJAKA AGAMEMNONA
}

\author{
ALEŠ MAVER
}

Že zaradi prestiža, ki ga ima Ajshilova trilogija v zgodovini slovenskega gledališča, je bila njena vnovična postavitev - na Slovenskem prva po dobrih petnajstih letih - na odru ljubljanske Drame nekako po definiciji eden osrednjih gledaliških dogodkov leta 2009. Toliko bolj, ker je bil z njo krščen tudi odlični novi prevod Oresteje, za katerega je poskrbel Marko Marinčič. O njem bi človek z nekaj več patetičnega talenta naše moderne mirno lahko ponovil za Župančičem, da je »velika maša slovenske besede«. A bi bila taka oznaka po drugi strani zgrešena, ker je Marinčičev prevod ravno pomnik zmožnostim povsem sodobne slovenščine v vseh njenih razsežnostih in ne le v tistih bolj privzdignjenih (kakor je bila to Cankarjeva Lepa Vida, ki ji je pesnik iz Vinice namenil svojo laskavo oznako). Utemeljeno je torej pričakovati, da bo v veljavi ostal vsaj tako dolgo kot Sovretov predhodnik. Vendar na tem mestu ne kanim govoriti o njem.

Raje si bom zastavil vprašanje, ali je podobno uspel njegov odrski krst pod taktirko Jerneja Lorencija in ali lahko vsaj nekoliko hodi vštric z legendarnim Korunovim krstom Sovretove različice Oresteje pred dobrimi štiridesetimi leti. Iskreno povem, da je bila moja prva misel takoj po odhodu iz dvorane nedvoumna: ne. Preveč me je zbodlo po moji sodbi nepotrebno in neuspešno eksperimentiranje v Prinašalkah pitnih darov. Vendar sem danes, ko je od ogleda predstave minilo že nekaj časa, prepričan, da posrečene poteze režiserja in obeh dramaturgov kljub vsemu krepko prevesijo tehtnico na stran vsaj prav dobre ocene.

Kot prvo tovrstno posrečeno potezo bi omenil dosledno zvestobo Ajshilovemu besedilu, kar je spričo dejstva, da je šlo za prvo uprizoritev novega prevoda, še toliko pomembneje. Lorenci ni sledil zgledu prenekaterega svojega kolega in svoje Oresteje ni spremenil v bojišče med tragiškim pesnikom in režiserjem, kjer slednji kajpak vedno zmaga, ker prevlada občutek, da brez njegovih radikalnih rezov v starodavni tekst ali brez aktualističnih dodatkov v podobi populističnih govorov politikov atenski pisci sploh ne bi mogli več nagovarjati sodobnega občinstva. Lorenci pokaže, da je takšno naziranje neumnost. Oprt na docela sodoben prevod lahko ustvari predstavo povsem za naš čas, ne da bi moral biti modrejši od Ajshila. Seveda pa to najbrž ne bi bilo mogoče, ko ne bi kljub zvestobi besedilu $\mathrm{z}$ enim udarcem razrešil dveh drugih zagat Oresteje. Najprej je tu vprašanje vloge zbora, ki bi v Ajshilovi različici, 
če bi ga režiser postavil na oder, že sam po sebi - veliko bolj kot pri Sofoklu - deloval kot močan potujitveni efekt. In dejansko bistveno otežil vstopanje gledalcev v predstavo. Zato so Lorenci in dramaturga zborov tekst - hkrati s tekstom nekaterih stranskih likov - razdelili med glavne like, predvsem pa ga zaupali dvema likoma, ki so ju uvedli na novo (in v Ajshilovi drami ne nastopata), Tantalu, davnemu predniku Agamemnonovega rodu, in nesrečni Agamemnonovi hčeri Ifigeniji. S tem pa predstavi novega zagona niso dali le z uprizoritveno-tehničnega vidika, marveč še bolj z vsebinskega.

Vstop Tantala in Ifigenije $\mathrm{v}$ trilogijo namreč odpravlja tisto nelagodje in neravnotežje, ki ga vsaj sam občutim ob branju Ajshilovih treh dram (očitno pa sta podobno razmišljala dramaturga). Gre za to, da se Oresteja giblje precej na robu prevlade črno-bele optike, kjer je Klitajmestrin morilski pohod prikazan kot vnebovpijoč greh, medtem ko je podobno Agamemnonovo ravnanje (zlasti ob Ifigeniji) povzdignjeno domala na raven boguvšečnega početja. Le malo zaleže ob tem občasno Ajshilovo rožljanje s prekletstvom Atrejevega rodu. In prav tu Lorencijeva postavitev doseže premik poudarka. Tantal in Ifigenija gledalca vseskozi opozarjata, da v orbito rodbinskega prekletstva sodijo tudi Klitajmestrina dejanja, ne samo dejanja 'junaka' Agamemnona.

Dodatno neravnotežje odpravi odrska upodobitev obeh protagonistov prve drame trilogije. Če Ifigenija ostaja nekako taka kot v Ajshilovem besedilu, je razgradnja herojskega Agamemnonovega lika, ki ga sam kljub nekaterim kritičnim tonom v trilogiji kljub vsemu vidim, popolna. Tisto, kar Ajshil s samovšečnim kraljevim pohodom čez rdečo preprogo bolj ali manj samo nakaže, Lorenci močno razširi. Agamemnon je pred gledalcem zgolj še kot samovšečni, ne pretirano bistri general s točo kolajn na prsih, kar še utrjuje afektirana, a posrečena interpretacija Mihe Nemca.

Naj zdaj nekaj besed namenim manj všečnim točkam uprizoritve. Prva je ponovno bolj tehnične narave. Na Slovenskem ima prevajanje dramskih besedil v verzih častitljivo tradicijo in razumljivo je, da se je vanjo kot vreden člen uvrstil tudi novi prevod Oresteje. A očitno se interpretacija verznih besedil na odru niti v 21. stoletju ne more znebiti pridiha nečesa lunatičnega. Tako je drdrajoče, pretirano afektirano izgovarjanje verzov s povsem zemeljsko vsebino nekaterih igralcev v motečem nasprotju s sodobnim jezikom in s sodobno vizualno podobo glavnine predstave (kar izrecno cementira denimo Orestov lik v predstavi). Ni mi povsem jasno, ali gre nemara za zavestno režiserjevo odločitev, s katero naj bi poudaril prepad, ki kljub vzporednicam loči antično in sodobno družbo, ali za kaj drugega. Za prvo možnost bi najbrž govorilo skrajno absurdno nakopičenje potujitvenih efektov v drugi polovici Prinašalk pitnih darov, katerega namen je lahko samo opozorilo na omenjeni prepad, saj sicer zgolj prelomi dramski lok in je bilo vsaj, kar mene zadeva, bistveni 
element za prvotno negativno oceno uprizoritve kot celote, in predstavlja še zdaj zame njen največji primanjkljaj.

Vtis nedvomno popravi tretja igra trilogije, Evmenide, kjer Lorenci nadaljuje z v Agamemnonu, pa tudi v Prinašalkah nakazano reinterpretacijo Oresteje in jo izjemno posrečeno sklene. Kot je v prvi drami na isto raven postavil maščevalno demonsko žensko Klitajmestro in puhoglavega vojaka Agamemnona, v drugi in tretji drami izrazito poudari enakost in solidarnost vseh mrtvih iz Tantalovega rodu (in verjetno tudi širše), ne glede na to, čigava roka jim je pomagala na oni svet. Kar kajpak spet ne bi bilo mogoče, ko ne bi že prej na oder postavil Tantala in Ifigenije. Morda postane v luči ustvarjanja omenjene solidarnosti, ko se preminuli ne delijo več na 'naše' (Orestove) in 'vaše' (Klitajmestrine) umrle, razumljivejša celo burleska iz Prinašalk. V Evmenidah končno pride do 'spopada' med svetom živih (ki se jim pridružijo 'mladi' bogovi) in poenotenim svetom mrtvih, ki se konča s simbolno likvidacijo slednjega - Evmenide in vse ostale mrtve iz Tantalovega rodu doleti vizualno učinkovito zaplinjenje v plinski celici. Moteči elementi, ki žive spominjajo na pretekle prestopke, so odstranjeni - morda nekakšna sodobna (ironična) inačica preobrazbe Erinij v Evmenide. S čimer se Lorencijevo branje Oresteje na neki način bliža Antigoni, zlasti Smoletovi. Navidezno prijazni, uradniški liki Apolona, Atene in Pitije se namreč bližajo uradniku Kreontu in njegovim sodelavcem, s katerimi je Smole najbolj nadgradil Sofokla.

Uprizoritev je slovenski javnosti vsekakor dostojno predstavila novi prevod. Posebej hvalevredno je, da je Lorenci s svojo ekipo lastno videnje Ajshila lahko uveljavil, ne da bi ga moral obrezovati ali mu dodajati iz svojega (z izjemo majhne, vsebinsko pomembne razširitve ob naštevanju nesreč Tantalidov).

Aleš Maver 